\title{
Appendices for Sustainable Development of the Tax System of Kazakhstan
}

\author{
G. A. Nassyrova ${ }^{1}$, A. E. Zhamiyeva ${ }^{1, *}$, M. S. Maramygin ${ }^{2}$, E. G. Knyazeva ${ }^{2}$, L. I. \\ Yuzvovich ${ }^{2}$ \\ ${ }^{1}$ L.N. Gumilyov Eurasian National University, Nur-Sultan, Kazakhstan \\ ${ }^{2}$ Ural State University of Economics, Ekaterinburg, Russia \\ ${ }^{*}$ Corresponding author. Email: zhami2805@mail.ru
}

\begin{abstract}
The article is devoted to the analysis of the growing trends in the sustainable development of the tax system of Kazakhstan in an unstable economy. The theoretical prerequisite is the lack of uniform methodological and methodological approaches to the definition, as well as to the formation and organization of the tax system, including in an extremely unstable economic situation. The article assesses the dynamics and structure of tax payments in the context of the economic crisis, offers modern tools of tax regulation. The main research methods were traditional: analysis and synthesis, systemic and institutional approaches, methods of induction and deduction, and the method of designing hypotheses was also used. The theoretical and practical significance of the study lies in substantiating the need to form an adaptive tax system to ensure sustainable growth of the national economy.
\end{abstract}

Keywords: tax regulation, crisis, tax system, taxation, economic growth, financial monitoring.

\section{INTRODUCTION}

Tax reforms in Kazakhstan in recent years have not yielded the expected results. The coronavirus pandemic and the state's restrictive measures have led to instability of tax legislation, a lack of revenue in the budgets of different levels. In an unfavorable economic environment, the task of forming a flexible tax policy that optimally combines the interests of the state and taxpayers is becoming especially urgent. In modern conditions, for the effective functioning of the tax system of Kazakhstan, there is an urgent need for its modernization, which ensures the most effective implementation of legislative requirements. It is for this purpose, within the framework of the implementation of the National Plan "100 Concrete Steps for the Implementation of Five Institutional Reforms", a new Tax Code was developed and adopted, which came into force in 2018. By its nature, the tax system is the result of the process of formation and development of tax relations, therefore, it is determined by many specific factors. Its current state is due to a certain stage that society has reached in its development. The current legislation, unfortunately, does not provide an accurate definition of the tax system, which quite often entails difficulties not only in theoretical research, but also in practice. Despite a significant amount of scientific research on the problems of tax relations, the current regulatory legal framework and law enforcement practice in the tax area need further harmonization and development [1].

\section{MATERIALS AND METHODS}

This study is based on certain theoretical provisions of the institutional theory using systemic, visual and synergetic methods, as well as the method of structural analysis. In most of the special literary sources, it is determined that the tax system of the state is a set of national and local taxes and fees levied in the manner prescribed by law. It should be noted that the aggregate of the named obligatory payments represents the taxation system, while the tax system covers a wider range of constituent elements. In our opinion, the tax system can be interpreted in the narrow and broad sense of the word. In particular, a broad view is illustrated by the authors who define the tax system as a set of all types of taxes, fees, mechanisms and methods of their collection, as well as tax authorities that ensure the timeliness and completeness of receipts of these obligatory payments to the budgets of various levels. In a narrow sense, the taxation system is only a set of taxes and fees, as well as methods, methods of calculating and paying them [2].

Modern national tax systems are based on the principles of taxation developed by A. Smith: universality and equality, certainty and convenience. These four principles of taxation, which have become classical, 
predetermine in the organization of the tax system giving priority to the taxpayer, respect for him [3]. Further development and systematization of the fundamental provisions of the theory of taxes was provided by the works of D. Ricardo, W. Petty, J.B. Seya, J. Mill [4]. The theory of A. Smith formed the basis for the concept of the leading role of the market in ensuring high rates of development by R. Lucas, J. Muth, M. Friedman, A. Laffer, J. Gilder. In their opinion, with such an approach, the tax base will expand; accordingly, with minimum taxes and maximum tax benefits, state revenues will increase [5]. J. M. Keynes, in turn, identifying the regulatory role of taxes and calling them "built-in mechanisms of flexibility", emphasized the incentive value of the tax system for entrepreneurship [6].

In the socialist system, taxation issues were removed from social ideology, and the theory of taxes was ousted from the system of economic sciences. The transition to a market economy required an appropriate tax system, as a result of which the theoretical and practical aspects of taxation have become the subject of numerous studies. Prominent Russian and Kazakh scientists were involved in taxation issues.

\section{RESULTS AND DISCUSSION}

Throughout the history of human development, economic contradictions and crises have been an unconditional stimulus for the development and improvement of the theory and practice of taxes. It was on the analysis of the experience of developed countries and their adaptation to the conditions of the modern external environment that the reform and development of the tax system of Kazakhstan was carried out. The evolution of the tax system of independent Kazakhstan can be conditionally represented in five stages. Periodization is proposed to be carried out on the basis of the principle of historicism and the sequence of amendments to tax legislation and taking into account the relevant editions of the Tax Code (Table 1).

In general, over the years of formation, measures were taken to strengthen the revenue side of the budget, a number of changes were made to the Tax Code, including revised rates and expanded incentive measures, formed a flexible, adaptive tax policy. In addition, an export customs duty on oil has been introduced, a mechanism for the distribution of import duties of the Customs Union has been developed and successfully implemented, and, in general, the discipline of paying taxes and customs payments has been strengthened [7].

As a result of the ongoing reforms, the formation of tax revenues to the budgets of all levels in Kazakhstan in its most general form is characterized by integrity and targeting, a clearer definition of the composition, structure and relationships of tax revenues. This applies primarily to the relationship between certain types of taxes. In this regard, the analysis and assessment of tax revenues and their structure allows you to identify the degree of impact on the economy. In particular, in the context of the economic crisis caused by the COVID19 pandemic, the composition, structure and volume of tax revenues have become unstable. Depending on the priorities of the country's development strategy, the current state of the national and world economy, foreign economic conditions and other factors, the structure of tax revenues undergoes significant changes (Table 2)

The analysis of the given data in Table 2 shows that tax revenues occupy a leading place in the total amount of state budget revenues. Their share for the years under study was in the range of $59-73 \%$. So in 2016 , there is an increase in budget revenues by $21.9 \%$ with an increase in

Table 1. Stages of evolution of the tax system of the Republic of Kazakhstan.

\begin{tabular}{|l|l|l|}
\hline Stage & The main direction of the stage & Stage characteristics \\
\hline $1.1991-1993$ & $\begin{array}{l}\text { Formation and origin of the tax } \\
\text { system of Kazakhstan as a sovereign } \\
\text { state }\end{array}$ & $\begin{array}{l}\text { Development of legislation on taxes and fees, its adjustment, } \\
\text { taking into account the experience gained in the conditions of a } \\
\text { transitional economy }\end{array}$ \\
\hline $2.1994-1997$ & Start of tax reform & $\begin{array}{l}\text { Formation of a tax system adapted to the conditions of a } \\
\text { developing market economy }\end{array}$ \\
\hline $3.1998-2009$ & Formation of the tax system & Qualitative transformations in the tax system \\
\hline $4.2009-2017$ & $\begin{array}{l}\text { Conceptual study of tax legislation, } \\
\text { formation of the tax system }\end{array}$ & $\begin{array}{l}\text { Development and systematization of tax legislation, integration of } \\
\text { the national tax system into the world }\end{array}$ \\
\hline $\begin{array}{c}\text { 5.2018 } \\
\text { present }\end{array}$ & $\begin{array}{l}\text { Adoption of a new edition of the } \\
\text { Tax Code providing for the concept } \\
\text { of taxpayer priority }\end{array}$ & $\begin{array}{l}\text { Tax legislative innovations, including preferences for online } \\
\text { trading platforms, investors, SMEs, improvement of tax } \\
\text { administration and VAT collection }\end{array}$ \\
\hline
\end{tabular}

Table 2. Dynamics of tax revenues in the total amount of state budget revenues of the Republic of Kazakhstan for 2016-2020, million tenge [8].

\begin{tabular}{|l|c|c|c|c|c|}
\hline Name & 2016 & 2017 & 2018 & 2019 & 2020 \\
\hline Growth rate of state budget revenues, $\%$ & 121.9 & 124.3 & 93.4 & 118.0 & 113.8 \\
\hline Growth rate of tax revenues, $\%$ & 123.3 & 113.1 & 115.8 & 116.8 & 92.9 \\
\hline Share of tax revenues in the total amount of state budget revenues, \% & 64.7 & 58.9 & 73.0 & 72.2 & 59.0 \\
\hline
\end{tabular}


tax revenues by $23.3 \%$. At the same time, the share of tax revenues in the total revenues of the state budget amounted to $64.7 \%$. The main reasons for this performance of incomes was the relative improvement in the macroeconomic situation and, accordingly, the indicators that illustrate it.

In 2017, the state budget revenues showed an even higher growth rate $-124.3 \%$, but at the same time the share of tax revenues in the total state budget revenues was only $58.9 \%$, there is also a decrease in the growth rate of tax revenues to $13.1 \%$. In other words, the growth of state budget revenues was ensured by the growth in the profitability of the National Fund of Kazakhstan, and not by tax revenues. With the planned volume of 196.02 billion tenge, the actual receipts for 9 months have already

$\mathrm{y}$ amounted to 1,6 billion tenge. By the way, in 2016, the investment income of the National Fund amounted to 415.1 billion tenge.

In 2018, despite the decrease in the total amount of state budget revenues due to the reduction in transfers, the amount of tax revenues increased by $15.8 \%$. This led to the fact that the share of taxes in the total amount of budget revenues was the maximum for the entire study period $73 \%$. This was due to GDP growth by $4.1 \%$, as well as an increase in production activity in the basic sectors of the economy. In 2019, there is an increase in budget revenues by $18 \%$, with a relative decrease in the share of tax revenues in the total revenues of the state budget $-72.2 \%$, against 73 in the previous year. The growth in tax revenues in 2019 was largely due to GDP growth by $4.5 \%$ and an increase in the production activity of enterprises. The fall in oil prices by more than $10 \%$ in 2019 was accompanied by a $6 \%$ decrease in oil revenues and was partially offset by the depreciation of the national currency. In 2020, there is an increase in state budget revenues by $13.8 \%$ and a simultaneous decrease in tax revenues by $7.1 \%$. The decrease in tax revenues in this period was caused by the slowdown in business activity in the business sector in the context of the pandemic crisis. The share of tax revenues in the total revenues of the state budget in 2020 decreased to $59 \%$, caused by an increase in the share of transfers and non-tax revenues due to increased dividend payments of national companies and revenues from the privatization of state property [9]. Thus, the analysis of the dynamics and structure of tax revenues illustrates the direct dependence of their volume and share in the composition of state budget revenues on the current state of the macroeconomic environment.

Analyzing the structure of tax revenues, we observe a significant role of corporate income tax and value added tax in the formation of the revenue side of the state budget, together, both of these taxes provide more than $53.5 \%$ (Figure 1).

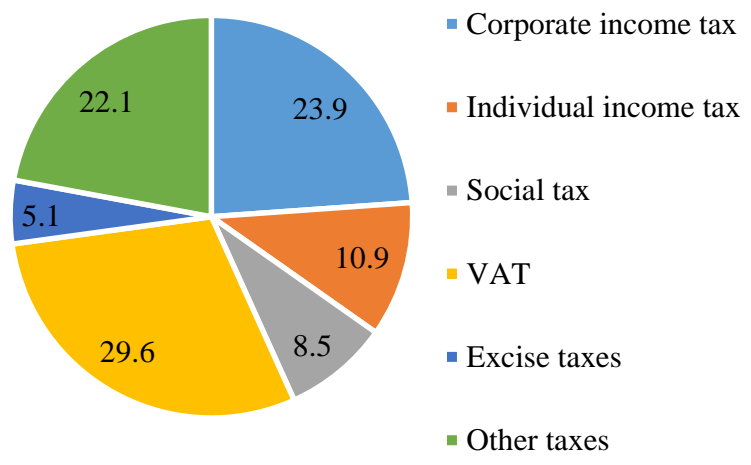

Figure 1 Structure of tax revenues to the state budget of Kazakhstan for $2020, \%$ [8].

If we consider the structure of indirect taxes, we can find that the most significant revenues in the state budget are provided by VAT. This is due to the fact that revenue from excise taxes is insignificant. So, the share of VAT accounted for in $2016-24.8 \%$, in $2017-24.4 \%$, in 2018 $25.8 \%$, in $2019-29.2 \%$, and in $2020-29.6 \%$ of all tax revenues of the state. budget. This reveals the growing dynamics of VAT, which indicates an increase in social pressure on consumer income.

During the analyzed period, namely for the period from 2016 to 2020, the largest changes in the structure of tax revenues can be traced in 2018 . In many ways, this can be explained by the unstable conditions in the global financial markets associated with the decline in prices for oil and other energy resources, devaluation of national currencies of both Kazakhstan and partner countries, and, accordingly, a change in the general regional economic picture. The crisis and the deterioration of the financial situation cannot cause a complete rejection of consumption among economic entities, which, in fact, supports the level of VAT as one of the most significant sources of state budget revenues [10]. The share of this "tax" in 2018 continued to grow, possibly also because consumer prices began to rise.

In 2020 , there is a tendency to optimize the structure of tax revenues of the consolidated budget. Thus, the share of individual income tax in the total volume of tax revenues increased to $10.9 \%$ against $9.5 \%$ in 2019 , the share of VAT was $29.6 \%$, slightly rising from $29.2 \%$. A positive fact was the upward trend in corporate income tax, which amounted to $23.9 \%$ (2019 - 21.4\%). The growth in the amount of corporate income tax receipts as a whole for the period under study is due to the growth of business activity in 2016-2019, respectively, to an increase in the volume of income from product sales.

During the analyzed period, there was an increase in almost all major types of taxes in absolute terms. The influence was exerted by such factors as: GDP growth, inflationary pressure, strengthening of the control activities of tax authorities. At the end of 2020, there is a decrease in VAT revenues caused by the government's restrictive measures in connection with the coronavirus infection [11]. 
Thus, about $64.3 \%$ of tax revenues to the budget are formed at the expense of three main taxes. For a comprehensive analysis of the taxation system, it is undoubtedly important to determine the role of direct and indirect taxes, since the influence of each of them on the economy is differentiated. Optimizing the ratio of direct and indirect taxes can ensure the effectiveness of tax policy. By managing this ratio, the state is able to exercise regulatory influence on the national economic system. Each state individually regulates the level of indirect and direct taxes that meet the state of the national economy, social objectives, to some extent determined by national history and mentality. In Kazakhstan, about $70 \%$ of all tax revenues to the budget come from entrepreneurial activity, which is a serious burden for business. But at the current stage of economic development and the level of income of the population, it is not possible to shift priorities. The purchasing power of citizens remains low [12]. The dynamics characterizing the structure of tax revenues in the Republic of Kazakhstan by the nature of tax collection is presented in Table 3.

The analysis of this table shows that in Kazakhstan the preference is given to direct taxes as the main source of tax revenues to the budget. Their share during 2016-2020 fluctuated from $65.4 \%$ to $72.8 \%$ of the total amount of tax revenues, while the share of indirect taxes in the structure of tax revenues in recent years has ranged from $28.2 \%$ to $34.6 \%$. This version of the government's tax policy can be explained by the fact that it most of all corresponds to the regulatory orientation of tax policy, rather than fiscal one, that is, it affects economic growth. In addition, the rate of growth of indirect taxes over the entire study period exceeds the rate of growth of direct taxes. Therefore, the optimization of the ratio between direct and indirect taxes in Kazakhstan as a strategic direction for increasing the efficiency of taxation remains a problem that requires an urgent solution.

Thus, today the question of reforming the taxation system, despite significant shifts, is absolutely legitimate. Strengthening the revenue base of the state is achieved throughout the world through large-scale or partial tax reforms, by optimizing the number and rates of taxes, changing the tax base, changing the ratio of different types of taxes, manipulating progressive and proportional taxation. These measures are carried out with the aim of increasing the flexibility of national tax systems, that is, their ability to quickly respond to the demands of the times. That is why the process of implementing the norms of the new Tax Code is going on quite actively now. However, the improvement of the institutional and legal support of the domestic taxation system should be accompanied by an increase in the fiscal efficiency of tax revenues by expanding the tax base and strengthening tax discipline.

Over the past decade, the system of tax control and tax administration in the Republic of Kazakhstan has been in a state of permanent reform. At the same time, the Government of the Republic of Kazakhstan was faced with the task of modernizing the tax system, which does not imply an increase in the rates of basic taxes [13].

In recent years, the Department of State Revenues of the Republic of Kazakhstan as an organizational and resource basis of the state tax policy has undergone significant changes due to the formation of marketoriented tax legislation, personnel modernization, the introduction of modern information technologies and methods of functioning. Despite the progress achieved in the field of cameral control and tax administration, there is an increase in arrears on the main types of taxes, which indicates their insufficient efficiency. Arrears peaks are synchronized with a certain regularity with the growing uncertainty in the economy of Kazakhstan. The arrears indicators testify to the deterioration of tax discipline of taxpayers, and the administrative measures applied to reduce the arrears of taxes and mandatory payments in some periods had a short-term effect. Arrears to the state budget have an unstable dynamic. The reasons for the growth are additional charges on acts of audits, charges on additional tax reports, including those presented based on the results of in-house audit and current obligations. Historically, the system of tax administration has relied primarily on individual or corporate tax returns to combat economic crime and ensure the completeness of government revenue. But in order to see the complete picture of today's taxpayers, it is necessary to access data from new sources, combining it with traditional information. Meeting the demands of digital tax administration also requires constant adaptation to economic fluctuations, citizen expectations, tax regulations, reporting requirements and digital technology.

In the era of digital technologies and social networks, the amount of information generated is increasing exponentially. Big Data is becoming a strategic asset. They represent a large amount of unstructured data from different sources and in different formats. This data can be used by both governments and businesses to create products that are ideal for consumers.

Table 3. Dynamics of the structure of tax revenues in Kazakhstan for 2016-2020, million tenge [8].

\begin{tabular}{|l|c|c|c|c|c|}
\hline \multirow{2}{*}{ Name } & \multicolumn{5}{c|}{ Specific gravity, \% } \\
\cline { 2 - 7 } & 2016 & 2017 & 2018 & 2019 & 2020 \\
\hline Tax revenues, including: & 100 & 100 & 100 & 100 & 100 \\
\hline Direct taxes & 72.8 & 72.5 & 70.3 & 67.1 & 65.4 \\
\hline Indirect taxes & 28.2 & 28.5 & 29.7 & 32.9 & 34.6 \\
\hline
\end{tabular}




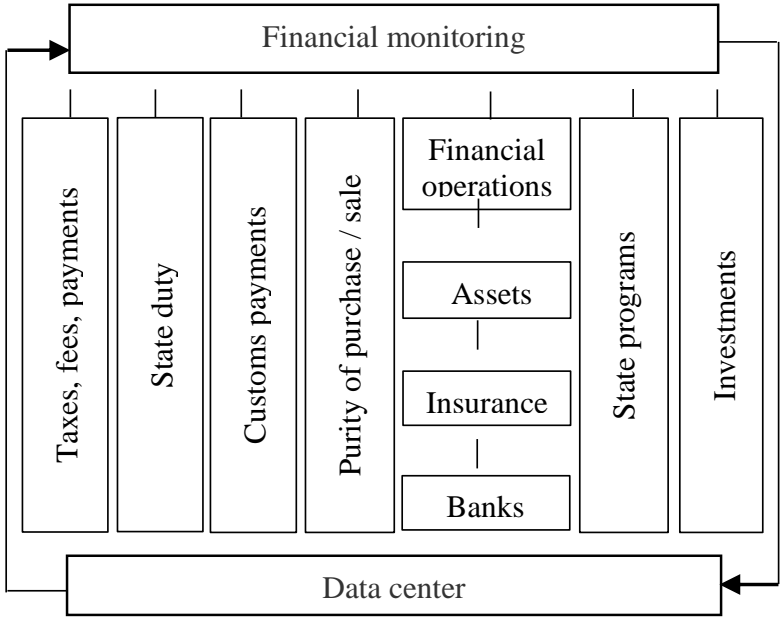

Figure 2 Financial data monitoring using the Data Center.

The introduction and more active application of Big Data technology in the tax administration system of the Republic of Kazakhstan will help to fight tax evasion and fraud, and also make the life of taxpayers easier [14]. Big Data implies the reuse of existing data, so this method of obtaining information can be considered relatively inexpensive. The use of Big Data increases the transparency of tax processes. And together with Block chain technology, it will be possible to track large transactions with high VAT, tax refunds and cross-border transactions. Big Data will help tax authorities better understand the behavior of the population and give a vision of where fraud is possible and the shadow economy develops, and where, on the contrary, there are conscientious taxpayers and there are no violations. That is, you can direct resources to where they are exactly needed.

Big Data can help tax authorities use analytical methods more widely, as the growing volume of data that becomes available for tax administration and additional volumes of information from third parties will become available as a result of planned amendments to the Tax Collection Law - will provide an extensive information repository for developing analytical methods for identifying new requirements, risks and taxpayers that bear such risks [15].

\section{CONCLUSIONS}

The lack of a clear structuring of the elements of tax revenues is becoming a serious obstacle to obtaining an adequate assessment of the impact of tax policy on various aspects of the socio-economic development of the state, in particular, the intensification of entrepreneurial activity, the growth of the well-being of the population, etc. Reflection of the structure of tax revenues of the state of the national economy and reveals the deformations of its development - only one side of the problem. On the other hand, it is extremely imprudent not to take into account the independent significance and influence of the internal structure of the tax system on the solution of strategic development problems. That is why the study and improvement of this structure makes it possible to effectively implement the objectively existing relationship and mutual influence of its individual components.

Unfortunately, this methodological position of consistency has not been adequately reflected in the domestic practice of forming tax relations and tax policy. The state tax policy should be aimed at balancing the budget, improving the quality of its implementation, adhering to the timing of the budget process and, as a result, ensuring socio-economic growth. Thus, the task of tax policy is to modernize the tax system in such a way as to achieve such an optimal level and conditions of taxation, which would form a balance of interests of the state and payers. The problem is that these interests are dynamic and depend on many factors, therefore, the parameters of the tax system that are optimal for certain conditions and at a particular moment in time cease to ensure a balance of interests with a change in the priorities of society development and the goals of the state's economic and social policy. In accordance with the current legislation, most taxes and fees are accumulated at the republican level, and then, in the form of transfers, some of them are returned to local budgets.

In this regard, Kazakhstan needs to form a tax system that will be aimed not only at increasing the amount of tax revenues, but also at their rational distribution among the levels of the budget system. Since the current state tax system can be characterized as insufficiently active and fiscal-oriented, which underestimates the regional and production factors of the development of the Kazakhstani economy. By its nature, the tax system is the result of the process of formation of tax relations, therefore, it is determined by many specific national factors. Its existence is due to a certain stage that society has reached in the field of taxation. For effective modernization of the tax system, it is necessary to establish an effective close relationship between the state, legal entities and individuals regarding the formation, distribution and use of their income. This is one of the main conditions for the optimal functioning of the financial and economic system, where taxes perform an appropriate linking function.

The implementation of the measures proposed in the article will help stimulate the development of the tax system, which will significantly increase revenues to the state and local budgets in the future.

\section{REFERENCES}

[1] A.N. Kozyrin, Forms of Systematization of Tax Legislation. Pravo. In: Zhurnal Vyssheyshkoly ekonomiki, 2017, pp. 73-82. DOI: https://doi.org/10.17323/2072-8166.2017.4.73.82.

[2] I.A. Mayburov, Tax and taxation, Unity, 2019.

[3] A. Smith, Wealth of Nations in 3 p, Urait, 2020.

[4] D. Ricardo, The Principles of Political Economy and 
Taxation, Dover Publications, 2010.

[5] E. L. Robert, An Agenda without a Plan, Economics as a Public Science, Part I: The Economist's Ethos and Modes of Persuasion 2019, pp. 289-314. DOI: https://doi.org/10.4000/ oeconomia.5605.

[6] J.M. Keynes, The General Theory of Employment, Interest, and Money, Urait, 2018.

[7] R. Lagravinese, P. Liberati, A. Sacchi, Tax buoyancy in OECD countries: New empirical evidence. In: Journal of Macroeconomics, 63 (2020) p. 103189. DOI: http://dx.doi.org/10.1016/j.jmacro.2020.103189.

[8] Statistical Bulletins of the Ministry of Finance of the Republic of Kazakhstan. http://www. Minfin.gov.kz.

[9] S. Amangeldinova, O. Protasova, L. Gorkovenko, Kazakhstan in new life realities during the coronavirus pandemic, Innovative economy: prospects for development and improvement 2020, pp. 13-19.

[10] I. Gersonskaya, Role and significance of state regulation at the present stage of economic development, The scientific heritage 2020, p. 32-35.

[11] J.T. Manhire, What does Voluntary Tax Compliance Mean? a Government perspective, 164 U.PA. L. 2015. http://www.pennlawreview.com /online/164U-Pa-L-Rev-Online-11.pdf.

[12] B. Aimurzina, A. Ismagulova State tax management in the Republic of Kazakhstan: current state and improvement. Actual problems of economics 2013, pp. 202-210.

[13] P.C. Abrantes; F. Ferraz, Big Data Applied to Tax Evasion Detection: A Systematic Review. In: International Conference on Computational Science and Computational Intelligence 2016, pp. 435-440. DOI: http://10.1109/CSCI.2016.0089.

[14] A.V. Maximov. BigData analysis as a kind of information and analytical technologies, Analytical technologies in the social sphere: theory and practice. Collection of student papers 2019, pp. 123-125.

[15] U. Sivarajah, M.M. Kamal, Critical analysis of Big Data challenges and analytical methods. In: Journal of Business Research 2017, pp. 263-286. DOI: http://10.1016/j.jbusres.2016.08.001. 